\title{
A Case of Hemangioma of the Hypopharynx treated with Photocoagulation Using KTP Laser
}

\author{
Tomoaki Mori ${ }^{1)}$, Toshikazu Shimane ${ }^{1)}$, Hidenori Kanai $^{2)}$, \\ Yukiomi Kushihashi ${ }^{3)}$ and Masako Terasaki ${ }^{3)}$
}

\begin{abstract}
We report herein on a case of hemangioma of the hypopharynx. A 72-year-old male was referred to our department with a tumor of the hypopharynx, discovered on gastrofiberoscopy. We diagnosed this tumor as a hemangioma. Excising hemangiomas carries the risk of severe bleeding, so photocoagulation with a KTP laser was performed for this patient. The tumor disappeared following photocoagulation with the KTP laser, and our results suggested that the KTP laser could be effective for the treatment of hemangiomas in the hypopharynx. Manufacture of this laser was however stopped in Japan in 2008, therefore some consideration is required to find an alternative system to the KTP laser.
\end{abstract}

Keywords : hemangioma, photocoagulation, KTP laser

\section{References}

1) Arnold WJ : Diseases of the Head and Neck (ed by Arnold WJ, Laissue JA, Friedmann I, et al.). pp 23-25, Thieme Publishing Group, New York, 1987.

2) Stell PM : Tumor of the hypopharynx. Scott-Brown's Otolaryngology 5 th ed (ed by Kerr AG, Groves J, Scott-Brown WG). pp 1-3, Butterworths, London, 1987.

3）小出千秋, 今井昭雄, 高橋淑子: 下咽頭良性腫傷の 2 症例. 日気食会報 43：492-499, 1992.

4）畑山尚生, 他：上咽頭血管腫の 1 例. 日耳鼻 93: 315, 1990.

5）竹内洋介, 大谷地直樹, 三浦 巧, 他 : 下咽頭に限局した 血管腫の 2 例. 耳喉頭䅡 62: 855-859, 1990.

6) McRae RD, Gatland DJ, McNab Jones RF, et al. : Malignant transformation in a laryngeal hemangioma. Ann Otol Rhinol Laryngol 99: 562-565, 1990.

7) Hirano S, Yamashita M, Kitamura M, et al. : Photocoagulation of microvascular and hemorrhagic lesions of the vocal fold with the KTP laser. Ann Otol Rhinol Laryngol 115: 253-259, 2006.

8）庄司和彦：口腔・咽頭血管腫に対する光凝固療法とは．耳 鼻咽喉科・頭頸部外科クリニカルトレンド Part II（野村恭 也, 本庄 䉷, 平出文久編)。178-179 頁, 中山書店, 東京, 1998.

9）児嶋久剛, 平野 滋, 庄司和彦: 喉頭血管腫の診断と治療. JOHNS 11: 729-732, 1995.

10）庄司和彦, 児嶋久剛：頭頸部手術一KTP レーザーの使用 経験. JOHNS 10: 800-804, 1994.

11) Shoji K, Kojima $H$ and Omori $K$ : Photo-coagulation of hemangioma in the pharynx and the larynx by KTP laser. Pract Otol (Kyoto) 87: 298-299, 1994.

12）平野 滋, 楯谷一郎, 岸本 曜, 他: グリーンレーザーを 用いた喉頭手術一KTP レーザーの後継として一. 日気食 会報 60：323-330, 2009 .
1) Department of Otolaryngology, Showa University Fujigaoka Hospital

2) Department of Otolaryngology, Showa University Hospital

3) Department of Otolaryngology, Odawara Municipal Hospital
Corresponding Author Address : Tomoaki Mori hujihujigaoka@yahoo.co.jp 


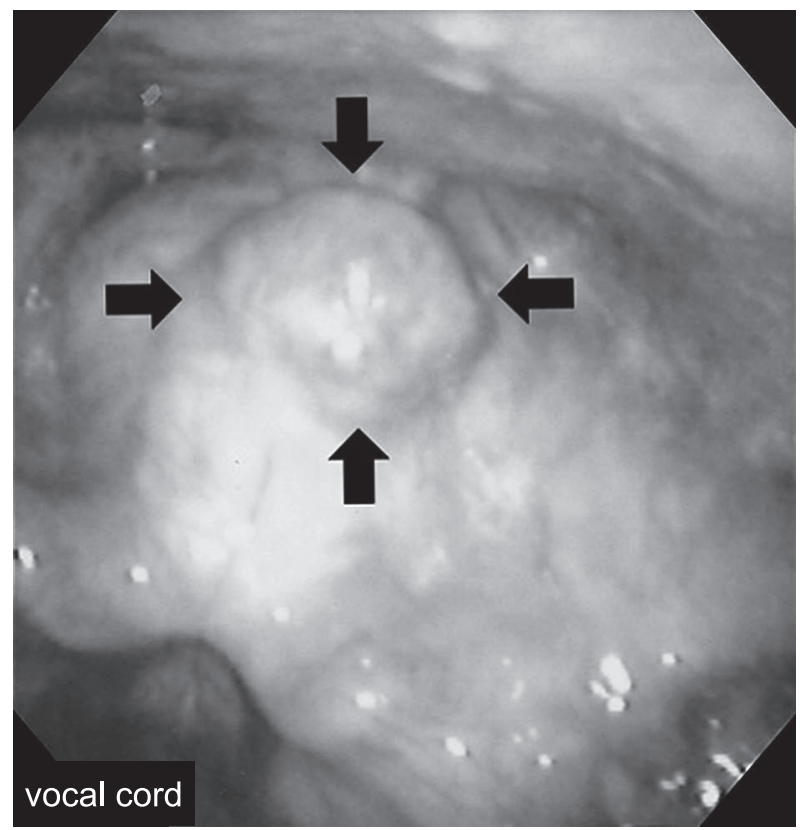

The endoscopic view showing a black tumor in the left arytenoid portion.

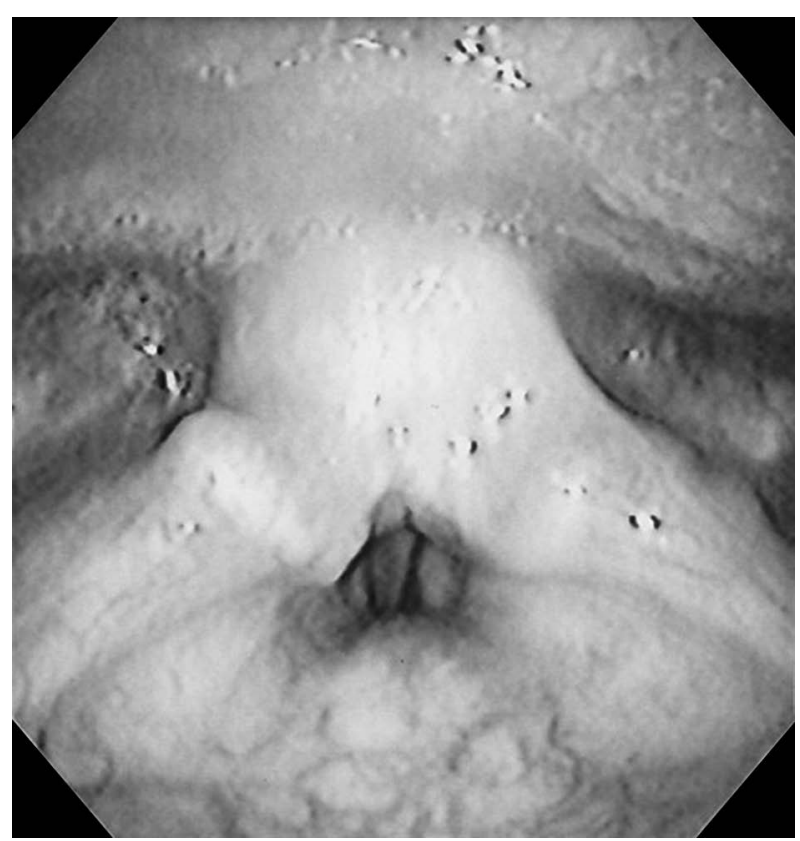

No residual tumor can be detected one month after the surgery. 